\title{
Association study of angiotensin converting enzyme gene polymorphism with elderly diabetic hypertension and lipids levels
}

\author{
Yun-Fei Zhou', Hui Yan², Xiao-Ping Hou' ${ }^{1}$ Jing-Li Miao', Jing Zhang ${ }^{1}$, Qiao-Xiang Yin ${ }^{1}$, Jun-Jie Li ${ }^{1}$, Xiao-Yan Zhang ${ }^{1}$,
} Yuan-Yuan Li ${ }^{1}$ and Hui-Lan Luo ${ }^{1 *}$

\begin{abstract}
Objective: To investigate the relationship between angiotensin converting enzyme (ACE) gene insertion/deletion (I/D) polymorphism and diabetic essential hypertension in elderly population.

Methods: Polymerase chain reaction (PCR) technique was used in 260 elderly normal control patients, 205 elderly hypertensive patients and 138 elderly diabetic hypertensive patients to detect the I/D polymorphism in ACE gene.

Results: DD genotype frequency (0.352) and D allele frequency (0.543) in elderly hypertensive patients were higher than those in the normal control patients. DD genotype (0.421) and D allele frequency (0.579) in elderly diabetic hypertensive patients were significantly higher than those in the control patients $(0.133$ and 0.250$)$. The differences of DD genotype and $D$ allele frequency between the elderly hypertensive patients and the elderly diabetic hypertensive patients were not significant $(P>0.05)$.
\end{abstract}

Conclusion: ACE gene deletion is a risk factor for hypertension but is not a risk factor for diabetes in elderly population. Keywords: Angiotensin converting enzyme gene, Insertion/deletion polymorphism, Elderly, Hypertension, Diabetic hypertension

\section{Introduction}

ACE is an important component of the renin - angiotensin system and plays an important role in hypertension and other cardiovascular and cerebrovascular diseases [1]. Type 2 diabetes is a polygenic complex disease caused by genetic factors and environmental factors [2], and the genetic factors are quite essential in the development of type 2 diabetes [3]. Many studies showed that the genetic polymorphisms of some genes related to metabolism were associated with type 2 diabetes [4], and the ACE gene polymorphism was one of them. There is a $287 \mathrm{bp}$ DNA fragment insertion (insertion, I)/deletion (deletion, D) polymorphism in intron 16 of ACE gene [5], which was studied in-depth in more and more basic researches [6-10]. And the association between the ACE gene polymorphism and the pathology of hypertension or diabetes has been paid

\footnotetext{
* Correspondence: Iuohuilan998@163.com

${ }^{1}$ The cadre ward of General Hospital of the Air Force PLA, No. 30, Fucheng Road, Haidian District, Beijing 100142, China

Full list of author information is available at the end of the article
}

more attention recently [7-9,11-15]. The present study aimed to explore the association of ACE gene polymorphism with hypertensive patients and with diabetic hypertension patients in elderly population in China.

\section{Subjects and methods \\ Subjects}

260 subjects were enrolled in the elderly control group (Male, $\mathrm{n}=150$, Female, $\mathrm{n}=110$ ), whose age were from 75 to 85 years $(81.6 \pm 4.55$ years). They were admitted to our hospital for medical examination and routine treatment from the October 2006 to March 2013. They did not have hypertension, diabetes, coronary heart disease or any other cardiovascular disease.

205 patients were enrolled in elderly hypertensive group (Male, $\mathrm{n}=103$, Female, $\mathrm{n}=102$ ), whose age were from 74 to 86 years (79.8 \pm 6.28 years). Diagnosis of essential hypertension was defined according to the WHO diagnostic criteria of hypertension, namely as systolic blood pressure $\geq$ $140 \mathrm{mmHg}$, diastolic blood pressure $\geq 90 \mathrm{mmHg}$. 


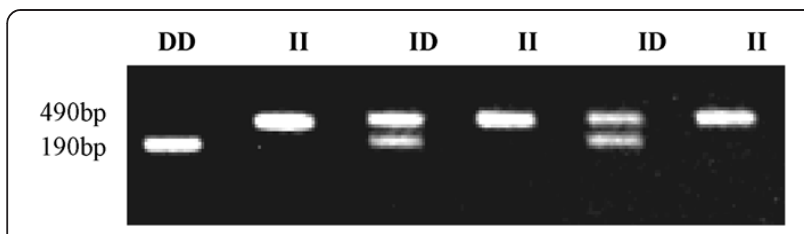

Figure 1 The genotyping results by $2.0 \%$ agarose.

138 patients were enrolled in elderly diabetic hypertension group (Male, $\mathrm{n}=70$, Female, $\mathrm{n}=68$, whose age were from 75 to 83 years $(79.12 \pm 5.21$ years). Diagnosis of diabetes is defined in accordance with the clinical criteria for diabetes.

\section{Methods}

\section{Ethical statement}

The present study has been performed with the approval of the ethics committee of General Hospital of the Air Force PLA and is in compliance with the Helsinki Declaration.

\section{Extraction of DNA template}

The rapid DNA extraction kit (Jinan Xinbeixi Biotechnology Co., Ltd. Jinan, China) was used for the extraction of the template DNA according to the protocol of the Kit.

\section{PCR amplification of the target fragment}

Genotyping was conducted in accordance with kit instructions of the ACE gene I/D polymorphism assay (Jinan Xinbeixi Biotechnology Co., Ltd., Jinan, China). The primers sequences as follows: Upstream: 5'CCCAGGCCG GGGACTCTGTA-3'; Downstream:5'AGCTCCAGCCCTT AGCTCACCT3'. Genomic DNA, dNTPs and TaqDNA polymerase were used for PCR mixture and each primer were used for ACE. The PCR steps were as the following: initial denaturation step at $94^{\circ} \mathrm{C}$ for 4 minutes, followed by
36 cycles of denaturation at $94^{\circ} \mathrm{C}$ for 50 seconds, annealing at $58^{\circ} \mathrm{C}$ for 30 seconds, extension at $72^{\circ} \mathrm{C}$ for 60 seconds and a final extension at $72^{\circ} \mathrm{C}$ for 5 minutes. Amplified products had two fragments: fragment with length of $490 \mathrm{bp}$ was defined I allele, fragment with length of $190 \mathrm{bp}$ was defined D allele. II genotype had only 1 band of $490 \mathrm{bp}$, ID genotype had both $490 \mathrm{bp}$ and $190 \mathrm{bp}$ bands, DD genotype had 1 band of 190 bp (Figure 1).

\section{Statistical analysis}

SPSS 13.0 software was utilized for the data analysis, The genotype frequencies and the allele frequencies of $\mathrm{ACE}$ gene among groups were compared using $X 2$ test, $P<0.05$ was considered significant difference.

\section{Results}

Hardy-Weinberg equilibrium test

ACE genotype distributions in three groups were in line with Hardy-Weinberg equilibrium (all $P>0.05$, data not shown).

\section{Genotype distribution}

Compared to the healthy control group, the frequency of ID and DD genotype was significantly higher in both elderly hypertensive patients group and in elderly hypertension with diabetes group $(\mathrm{P}<0.001)$. Similarly, the $\mathrm{D}$ allele frequency was also higher in these two groups comparing to the control group. We did not find significant significance between elderly hypertensive group and elderly hypertension with diabetes group in genotype or allele frequency (Table 1).

\section{Serum glucose and lipid levels in different genotypes}

TG and LDL-C levels in patients with ID and DD genotype were significantly higher than those in patients

Table 1 ACE genotype and allele frequencies in elderly control group, elderly hypertensive group and elderly hypertensive and diabetic group

\begin{tabular}{|c|c|c|c|c|c|c|}
\hline Groups & $\mathbf{n}$ & Genotypes & & & Allele & \\
\hline & & $\|$ & ID & DD & I & $D$ \\
\hline Control group & 260 & 31 (11.9) & $60(23.1)$ & $169(65.0)$ & 23.5 & 76.5 \\
\hline Hypertension group & 205 & $61(29.8)^{*} \#$ & $78(38.0)^{*} \#$ & $66(32.2)^{*} \#$ & $48.8^{*} \#$ & 51.2 \\
\hline Hypertension with diabetes group & 138 & $44(31.9)^{* *}$ & $51(37.0)^{* *}$ & $43(31.1)^{* *}$ & $0.50^{* *}$ & 0.50 \\
\hline
\end{tabular}

Note: Between the elderly hypertensive group and the control group: ${ }^{*} X^{2}$ for genotypes $=20.09, P<0.001, X^{2}$ for alleles $=23.63, P<0.001$. Between the elderly hypertensive and diabetic group and the control group, ${ }^{* *} X^{2}$ for genotypes $=10.62, P<0.001, X^{2}$ for alleles $=22.4, P<0.001$. Between the elderly hypertensive group and the elderly hypertensive and diabetic group, $\# x^{2}$ for genotypes $=0.68, P>0.05, X^{2}$ for alleles $=0.29, P>0.05$.

Table 2 Lipids and glucose levels between each genotypes

\begin{tabular}{cccccc}
\hline Genotypes & TG (mmol/L) & TC (mmol/L) & HDL-C (mmol/L) & LDL-C (mmol/L) & Glucose (mmol/L) \\
\hline$\|$ & $1.4 \pm 0.2$ & $5.4 \pm 1.1$ & $0.9 \pm 0.3$ & $2.4 \pm 1.1$ & $4.6 \pm 0.8$ \\
ID & $1.8 \pm 0.4^{*}$ & $6.3 \pm 1.7^{*}$ & $1.2 \pm 0.4^{*}$ & $3.1 \pm 1.2^{*}$ & $5.7 \pm 1.2^{*}$ \\
DD & $1.9 \pm 0.3^{* *}$ & $6.5 \pm 1.4^{* *}$ & $1.3 \pm 0.3^{* *}$ & $3.3 \pm 1.3^{* *}$ & $6.4 \pm 1.3^{* *}$ \\
\hline
\end{tabular}


with II genotype, the difference of blood glucose levels were not statistically significant in different genotypes $(P>0.05)$, Table 2 .

\section{Discussion}

Epidemiological studies show that the hypertension is a polygenic disease, and the genetic and environmental factors were involved in the pathogenesis of hypertension together. ACE is the key enzyme in renin - angiotensin system, which can catalyze the conversion of angiotensinI to angiotensin II and is the ACE protein coding gene $[2,15]$. ACE gene exists in chromosome $17 \mathrm{q} 23$ and contains 26 exons and 25 introns with a total length of $21 \mathrm{~kb}$. Accordance with the presence or absence of $287 \mathrm{bp}$ fragment in intron 16, there is an insertion/deletion (I/D) polymorphism. Some studies confirmed the presence of three genotypes: deletion homozygous genotype DD, insertion homozygous genotype II and heterozygous genotype ID.

Type 2 diabetes is a complex polygenic disease caused by genetic factors and environmental factors, of which, the genetic factors play the important role in the development of type 2 diabetes [3]. In recent years, the relationship between ACE gene polymorphism and type 2 diabetes was inconsistent among different reports. For example, in a recent published meta-analysis [16] report showed that a total of 41 studies including 4708 cases and 5368 controls were pool analyzed the association between ACE I/D polymorphism and T2DM in a Chinese population. The authors found the pooled ORs for the association between ACE I/D polymorphism and T2DM risk were not statistically significant under all genetic models (co-dominant model: DD vs. II: OR $=1.17,95 \%$ CI $0.97-1.42$ and ID vs. II: $\mathrm{OR}=1.01,95 \%$ CI $0.93-1.10$; dominant model: $\mathrm{OR}=1.06$, 95\% CI 0.94-1.19; multiplicative model: $\mathrm{OR}=1.08,95 \%$ CI $0.98-1.18$ ). However, Zarouk et al. [17] reported that the DD genotype and the $\mathrm{D}$ allele are associated with hypertension and type 2 diabetes in Egyptian patients.

In the present study, we utilized the case - control study to analyze the relationship between the ACE gene polymorphism and elderly hypertension and diabetic hypertension. The role of ACE gene in essential hypertension remained controversial. Woo et al. [18] reported ACE gene was not observed to be associated with essential hypertension. However, in another population-based study, the D allele was found to be associated with hypertension [19]. In addition, Kenric et al. also found that the $\mathrm{D}$ allele was associated with hypertension in a group of African Americans [20].

In this study, between elderly hypertensive group, elderly hypertensive with diabetes group and healthy control group, the frequencies of ID and DD genotype in ACE gene, as well as the frequency of D allele, were significantly increased. Indicating that ACE gene deletion polymorphism was associated with the pathogenesis of hypertension in elderly. The present study also found that the ACE gene I/D polymorphism was not a risk factor for type 2 diabetes in the elderly population, which was consistent with some reports [21-23]. In addition, this study also found that in the different genotypes, TG and LDL-C levels in D allele carriers significantly increased, but it had no effect on blood glucose levels. The mechanism of ACE gene polymorphism affects the lipid levels was unclear, which is worth further exploring.

\section{Conclusion}

In summary, in Chinese elderly population, DD genotype and D allele in ACE gene were associated with hypertension and lipid levels. However, they were not risk factors for type 2 diabetes in Chinese elderly population.

\section{Competing interests}

The authors declared no competing interests exist.

\section{Authors' contributions}

YFZ and HLL carried out the molecular genetic studies and drafted the manuscript. HY and JZ carried out the genotyping. QX, JJL, and XYZ participated in the design of the study and performed the statistical analysis. YYL conceived of the study, and participated in its design and coordination and helped to draft the manuscript. All authors read and approved the final manuscript.

\section{Author details}

${ }^{1}$ The cadre ward of General Hospital of the Air Force PLA, No. 30, Fucheng Road, Haidian District, Beijing 100142, China. ${ }^{2}$ Combination of traditional Chinese and Western Medicine Hospital of Southern Medical University, Guangzhou 510515, China.

Received: 10 November 2013 Accepted: 13 December 2013

Published: 19 December 2013

\section{References}

1. Xia H, Sriramula S, Chhabra KH, Lazartigues E: Brain Angiotensin-converting enzyme type 2 shedding contributes to the development of neurogenic hypertension. Circ Res 2013, 113(9):1087-96.

2. Chaoxin J, Daili S, Yanxin H, Ruwei G, Chenlong W, Yaobin T: The influence of angiotensin-converting enzyme 2 gene polymorphisms on type 2 diabetes mellitus and coronary heart disease. Eur Rev Med Pharmacol Sci 2013, 17(19):2654-9.

3. Wang CH, Ke WS, Lin E: Evaluation of the ENPP1 and PLIN single nucleotide polymorphisms with type 2 diabetes in a Taiwanese population: evidence for replication and gene-gene interaction. J Investig Med 2012, 60(8):1169-73.

4. Muñoz-Barrios S, Guzmán-Guzmán IP, Muñoz-Valle JF, Salgado-Bernabé AB, Salgado-Goytia L, Parra-Rojas I: Association of the HindIII and S447X polymorphisms in LPL gene with hypertension and type 2 diabetes in Mexican families. Dis Markers 2012, 33(6):313-20.

5. Zarouk WA, Hussein IR, Esmaeil NN, Raslan HM, Reheim HA, Moguib O, Emara NA, Aly AA, Hamed M: Association of angiotensin converting enzyme gene (I/D) polymorphism with hypertension and type 2 diabetes. Bratis/ Lek Listy 2012, 113(1):14-8.

6. Al-Rubeaan K, Siddiqui K, Saeb AT, Nazir N, Al-Naqeb D, Al-Qasim S: ACE I/D and MTHFR C677T polymorphisms are significantly associated with type 2 diabetes in Arab ethnicity: a meta-analysis. Gene 2013, 520(2):166-77.

7. Al-Harbi EM, Farid EM, Gumaa KA, Darwish AH, Alenizi M, Singh J: Genetic combination of angiotensin-converting enzyme with methylene tetrahydrofolate reductase polymorphisms and the risk of type 2 diabetes mellitus in Bahrain. J Renin Angiotensin Aldosterone Syst 2013. doi: $10.1177 / 1470320313478286$. 
8. Purnamasari $D$, Widjojo $B D$, Antono $D$, Syampurnawati M: ACE gene polymorphism and atherosclerotic lesion of carotid artery among offsprings of type 2 diabetes mellitus. Acta Med Indones 2012, 44(2):128-34.

9. Narne P, Ponnaluri KC, Singh S, Siraj M, Ishaq M: Relationship between angiotensin-converting enzyme gene insertion/deletion polymorphism, angiographically defined coronary artery disease and myocardial infarction in patients with type 2 diabetes mellitus. J Renin Angiotensin Aldosterone Syst 2012, 13(4):478-86.

10. Mansoor Q, Javaid A, Bilal N, Ismail M: Angiotensin-converting enzyme (ACE) gene II genotype protects against the development of diabetic peripheral neuropathy in type 2 diabetes mellitus. J Diabetes 2012, 4(3):257-61.

11. Sinorita H, Madiyan M, Pramono RB, Purnama LB, Ikhsan MR, Asdie AH: ACE gene insertion/deletion polymorphism among patients with type 2 diabetes, and its relationship with metabolic syndrome at Sardjito Hospital Yogyakarta, Indonesia. Acta Med Indones 2010, 42(1):12-6.

12. Niu W, Qi Y, Gao P, Zhu D: Angiotensin converting enzyme $D$ allele is associated with an increased risk of type 2 diabetes: evidence from a meta-analysis. Endocr J 2010, 57(5):431-8.

13. Chmaisse HN, Jammal M, Fakhoury H, Fakhoury R: A study on the association between angiotensin-I converting enzyme I/D dimorphism and type-2 diabetes mellitus. Saudi J Kidney Dis Transpl 2009, 20(6):1038-46.

14. Rasyid H, Bakri S, Yusuf I: Angiotensin-converting enzyme gene polymorphisms, blood pressure and pulse pressure in subjects with essential hypertension in a South Sulawesi Indonesian population. Acta Med Indones 2012, 44(4):280-3.

15. Zhu M, Zhang J, Nie S, Yan W: Associations of ACE I/D, AGT M235T gene polymorphisms with pregnancy induced hypertension in Chinese population: a meta-analysis. J Assist Reprod Genet 2012, 29(9):921-32.

16. Zhou D, Ruiter R, Zhang J, Zhou M, Liu H, Liu W, Wang S: Angiotensinconverting enzyme I/D polymorphism is not associated with type 2 diabetes in a Chinese population. J Renin Angiotensin Aldosterone Syst 2012, 13:372-8.

17. Bhaskar LV, Mahin S, Ginila RT, Soundararajan P: Role of the ACE ID and PPARG P12A Polymorphisms in Genetic Susceptibility of Diabetic Nephropathy in a South Indian Population. Nephrourol Mon 2013, 5(3):813-817.

18. Woo SW, Bang S, Chung MW, Jin SK, Kim YS, Lee SH: Lack of association between $\mathrm{ACE}$ and bradykinin $\mathrm{B} 2$ receptor gene polymorphisms and ACE inhibitor-induced coughing in hypertensive Koreans. J Clin Pharm Ther 2009, 34(5):561-7.

19. He Q, Fan C, Yu M, Wallar G, Zhang ZF, Wang L, Zhang X, Hu R: Associations of ACE Gene Insertion/Deletion Polymorphism, ACE Activity, and ACE mRNA Expression with Hypertension in a Chinese Population. PLoS One 2013, 8(10):e75870.

20. Zivko M, Kusec R, Galesić K: Impact of angiotensin-converting enzyme gene polymorphism on proteinuria and arterial hypertension. Coll Antropol 2013, 37:765-770.

21. Arfa I, Nouira S, Abid A, Bouafif-Ben Alaya N, Zorgati MM, Malouche D, Manai I, Ben Rayana MC, Blousa-Chabchoub S, Ben Romdhane H, Ben Ammar MS, Ben Salah A, Abdelhak S: Lack of association between renin-angiotensin system (RAS) polymorphisms and hypertension in Tunisian type 2 diabetics. Tunis Med 2010, 88(1):38-41.

22. Tascilar N, Dursun A, Ankarali H, Mungan G, Ekem S, Baris S: Angiotensinconverting enzyme insertion/deletion polymorphism has no effect on the risk of atherosclerotic stroke or hypertension. J Neurol Sci 2009, 285(1-2):137-41.

23. Arfa I, Abid A, Nouira S, Elloumi-Zghal H, Malouche D, Mannai I, Zorgati MM, Ben Alaya N, Rebai A, Zouari B, Ben Ammar S, Ben Rayana MC, Hmida S, Blousa-Chabchoub S, Abdelhak S: Lack of association between the angiotensin-converting enzyme gene (I/D) polymorphism and diabetic nephropathy in Tunisian type 2 diabetic patients. J Renin Angiotensin Aldosterone Syst 2008, 9(1):32-6.

doi:10.1186/1476-511X-12-187

Cite this article as: Zhou et al:: Association study of angiotensin converting enzyme gene polymorphism with elderly diabetic hypertension and lipids levels. Lipids in Health and Disease 2013 12:187.

\section{Submit your next manuscript to BioMed Central and take full advantage of:}

- Convenient online submission

- Thorough peer review

- No space constraints or color figure charges

- Immediate publication on acceptance

- Inclusion in PubMed, CAS, Scopus and Google Scholar

- Research which is freely available for redistribution 